\title{
INCREASING CADET'S READING COMPREHENSION THROUGH QUESTIONING AND ANSWERING METHOD
}

\author{
Meita Maharani $\mathbf{S}^{1}$
}

1)Politeknik Penerbangan Surabaya

Jl. Jemur Andayani I, No. 73 Surabaya 60236

Email : meitamaharanisukma@yahoo.com

\begin{abstract}
The aims of this research were to find out whether there was a significant difference of cadets' reading comprehension achievement before and after being taught through questioning and answering method and to find if there was an increase of cadets' reading comprehension after the instruction. The sample of this research was course TNU 10 A/B in Aviation Polytechnic of Surabaya. The research applied one group pre-test postest design. The result of the reading study by using questioning and answering method showed that there was a significant difference on cadets' reading comprehension. The average of postest score was higher than that of pre-test, and it has gain. It means that there is an increase of cadets' reading comprehension achievement after being taught through questioning and answering method type of cooperative learning.
\end{abstract}

Keywords: cooperative learning, questioning and answering method, reading comprehension.

\section{INTRODUCTION}

English should be mastered by the cadets from junior high school to university level, but many of them get difficulties when they try to understand the knowledge from a book, internet and article. One of the ways that should be done by the cadets to get the knowledge is reading. Reading comprehension is the ability to understand a written passage of text. It means that it allows the reader to interact with the text and try to interpret the text in a meaningful way. For many, reading comprehension also unlocks the door to a lifetime of reading recreation and enjoyment. Reading comprehension is the process of extracting and constructing meaning through interaction and involvement with written language.

There are five aspects of reading which the cadets should understand to comprehend a text well, they are determining main idea, finding specific information, reference, inference, and vocabulary. Comprehension can be regarded as a condition where certainly exist. Beside a pleasure activity that can increase the reader's knowledge about the information from the text, in language class reading can also consolidate and extend the reader's knowledge and skill in language.

Based on the statements above, it can be inferred that when the reader is reading a text, cadets becomes the most important thing in reading activity. Comprehension will make the reader able to determine the essence of the sentence or text and receive the main purpose of reading process. It is necessary for the cadets because by comprehension the cadets can get the aim of reading text, beside that, by comprehending the text the cadets will find the gist of the text such as an important message or information from the text, as defined by Djuharie (2008) reading comprehension is understanding of written text meaning to get the information which is needed from the text as efficiently as possible, when the cadets find the difficulties in reading, the lecturer should be able to solve this problems. As defined by Woolley (2011), cooperative learning is an approach to organizing classroom activities into academic and social learning experiences. This statement means that it differs from group work, and it has been described that cadets must work in groups to complete tasks collectively toward academic goals, while we are teaching in the class, it is important to make the class fun and active, by using questioning and answering method type of cooperative 
learning, we can make all of cadets in the class become more interactive and involving themselves into the class's activities. Curran (1994), states that this type can make the cadets' interest increase and interfere to the interactive situation in the class. It is why the lecturer should use Questioning and answering method type of cooperative learning to make the cadets easier to comprehend the text., without comprehension, reading would be empty and meaningless.

Many cadets have difficulties in comprehending the reading text because of lack of vocabulary, uninteresting strategy, lack of background knowledge, and ignoring reading technique. Schumm (2006) says that comprehension process involves an understanding of words and how these words are used to create meaning. In order to help the cadets comprehend the text, questioning and answering method type of cooperative learning was implemented. In accordance with the theories previously presented, the present study aims to investigate whether there was significant difference and increase of cadets' reading comprehension after being taught through questioning and answering method. From the cases, the researcher used questioning and answering method type of cooperative learning to increase cadets' reading comprehension at course TNU $10 \mathrm{~A} / \mathrm{B}$.

\section{METHOD}

This research was quantitative research. According to Setiyadi (2006), quantitative research is a kind of research in which the data tended to use statistic as measurement in deciding the conclusion. In conducting this research, the researcher used One Group Pretest Postest Design. In this research, the cadets were given pre test before treatments and in the end of the research the cadets were also given post test after giving treatments. The design of the research is illustrated as follow:

$$
\mathrm{T} 1 \rightarrow \mathrm{X} \rightarrow \mathrm{T} 2
$$

Notes:

T1 : Pre test

T2 : Post test

X : Treatment

The treatment was conducted into three meetings of activities and each meeting took $2 \times 50$ minutes. The population of this research was all the first grade cadets at Aviation Polytechnic of Surabaya. There were seven classes available at the first grade. From those classes, the reseacher took one class as the try out class; it was class 10 A consisting of 24 cadets and one class as the experimental class, it was class $10 \mathrm{~B}$ consisting of 25 cadets.

In collecting the data, the researcher used pretest and postest. Pretest was administered in order to find out the cadets' reading comprehension before the treatments, and postest was administered in order to find out the increase of the treatments towards the cadets' reading comprehension after being given the treatments. Pretest and postest were used to get the data to analyze the hypothesis.

\section{RESULTS AND DISCUSSION}

This research was primaly aimed at answering the question whether there was a significant difference of cadets' reading comprehension before and after being taught through questioning and answering method type of cooperative learning and whether there was an increase of cadets' reading comprehension after being taught through questioning and answering method type of cooperative learning or not. In this discussion, the researcher interprets the findings by comparing with the findings of the previous studies and the theories as follow :

1. The relevance of the current research with the findings of the previous researches. 
The writer has explained briefly before in the chapter two that there were some researches related to this study. As the research that had been conducted by Febriana (2011) conducted a research about implementation of questioning and answering method type of cooperative learning, by implementing cooperative learning model type questioning and answering method, the lecturer can improve the cadets' achievement on social learning and make the class become more active. A research about understanding the ability of Two Variables Linear Equation Systems. They found that questioning and answering method type of Cooperative Learning has positive influence for purposing to understanding the ability of Two Variables Linear Equation Systems. From the two previous studies, there were some issues that were investigated. The most issue was using questioning and answering method type of cooperative learning can give positive influence to the cadets, it made the cadets able to understand about the material easily. Another issue was by using Questioning and answering method type of cooperative learning, the lecturer could make the cadets more fun and active in class activity.

2. The relevance of the finding with the theories

Reading skill is very complex, therefore it consequently is difficult to be mastered. There are five aspects of reading which the cadets should understand to comprehend a text well, they are determining main idea, finding specific information, reference, inference, and vocabulary, that reading is ranked first among the academic skills that they wish to gain mastery over and Reading is the most crucial skill to master due to several reasons. Reading comprehension is the ability to understand a written passage of text. It means that it allows the reader to interact with the text and try to interpret the text in a meaningful way. For many, reading comprehension also unlocks the door to a lifetime of reading recreation and enjoyment, that reading comprehension is the process of extracting and constructing meaning through interaction and involvement with written language.

The first result of the research indicated that the difference of TNU 10 A cadets' reading comprehension score in the experimental class after treatments was significant. It can be seen for the mean of pre-test and postest, the average score is 70,67 for pre-test score and 73,81 for postest score. As mentioned before, questioning and answering method type of cooperative learning can increase cadets' reading comprehension significantly

\begin{tabular}{lr|r|r|r|r} 
& $\mathrm{N}$ & Minimum & Maximum & Mean & Std. Deviation \\
\hline PRETEST2 & 24 & 60,00 & 73,00 & 65,0833 & 4,51005 \\
\hline PRETEST1 & 24 & 60,00 & 73,00 & 66,1667 & 4,18763 \\
\hline PRETEST3 & 24 & 67,00 & 78,00 & 73,3750 & 3,41114 \\
\hline PRETEST4 & 24 & 70,00 & 82,00 & 78,0833 & 3,10563 \\
\hline Valid N (listwise) & 24 & & & & \\
\hline
\end{tabular}

\begin{tabular}{|c|c|c|c|c|c|}
\hline \multicolumn{6}{|c|}{ Result pretest score of TNU $10 \mathrm{~A}$} \\
\hline & $\mathrm{N}$ & Minimum & Maximum & Mean & Std. Deviation \\
\hline POSTEST1 & 25 & 60,00 & 72,00 & 69,0000 & 3,09570 \\
\hline POSTEST2 & 25 & 60,00 & 72,00 & 69,6800 & 2,47857 \\
\hline POSTEST3 & 25 & 70,00 & 83,00 & 75,0800 & 4,14246 \\
\hline POSTEST4 & 25 & 75,00 & 88,00 & 81,4800 & 3,28024 \\
\hline Valid N (listwise) & 25 & & & & \\
\hline
\end{tabular}

Result postest score of TNU $10 \mathrm{~A}$

The second result of the research indicated that the difference of TNU 10 B cadets' reading comprehension score in the experimental class after treatments was significant. It can be seen for the mean of pre-test and postest, the average score is 70,56 for pre-test score and 73,97 for postest score. As mentioned before, questioning and answering method type of cooperative learning can increase cadets' reading comprehension significantly. 


\begin{tabular}{lr|r|r|r|r} 
& $\mathrm{N}$ & Minimum & Maximum & Mean & Std. Deviation \\
\hline PRETEST2 & 25 & 60,00 & 73,00 & 65,0800 & 4,64507 \\
\hline PRETEST1 & 25 & 60,00 & 72,00 & 65,8800 & 4,02409 \\
\hline PRETEST3 & 25 & 69,00 & 78,00 & 74,4800 & 2,72519 \\
\hline PRETEST4 & 25 & 70,00 & 82,00 & 76,8000 & 3,95811 \\
\hline Valid N (listwise) & 25 & & & & \\
\hline
\end{tabular}

\section{Result pretest score of TNU $10 \mathrm{~B}$}

\begin{tabular}{|lr|r|r|r|r} 
& $N$ & Minimum & Maximum & Mean & Std. Deviation \\
\hline POSTEST1 & 25 & 60,00 & 72,00 & 69,3600 & 3,22594 \\
\hline POSTEST2 & 25 & 60,00 & 73,00 & 70,0400 & 2,68452 \\
\hline POSTEST3 & 25 & 70,00 & 83,00 & 74,7200 & 4,04681 \\
\hline POSTEST4 & 25 & 78,00 & 88,00 & 81,7600 & 2,89079 \\
\hline Valid N (listwise) & 25 & & & & \\
\hline
\end{tabular}

\section{Result postest score of TNU $10 \mathrm{~B}$}

Based on the data of five aspects in reading, the correct answer of each aspects increase from pre-test to postest. In determining main idea increase from pre-test to postest, finding specific information, inference, reference and vocabulary also increase from pre-test to postest. The highest increase is in reference aspect because cadets felt easier to understand the material of reference when the lecturer taught and when answered the tests that were given. The lowest increase is in inference aspect because the cadets got difficulties to find wrong statement or true statement related to the text, but generally the five aspects of reading increased from pre-test when they did not get treatment yet to postest.

\begin{tabular}{llr|r|r|r} 
& PRETEST1 & PRETEST2 & PRETEST3 & PRETEST4 \\
\hline $\mathrm{N}$ & Valid & 24 & 24 & 24 & 24 \\
\cline { 2 - 6 } & Missing & 0 & 0 & 0 & 0 \\
\hline Mean & 66,1667 & 65,0833 & 73,3750 & 78,0833 \\
\hline Minimum & 60,00 & 60,00 & 67,00 & 70,00 \\
\hline Maximum & 73,00 & 73,00 & 78,00 & 82,00 \\
\hline
\end{tabular}

Mean, minimum and maximum pretest score of TNU 10 A

\begin{tabular}{|c|c|c|c|c|c|}
\hline \multirow{3}{*}{$\bar{N}$} & & POSTEST1 & POSTEST2 & POSTEST3 & POSTEST4 \\
\hline & Valid & 25 & 25 & 25 & 25 \\
\hline & Missing & 0 & 0 & 0 & 0 \\
\hline \multicolumn{2}{|c|}{ Mean } & 69,0000 & 69,6800 & 75,0800 & 81,4800 \\
\hline \multicolumn{2}{|c|}{ Minimum } & 60,00 & 60,00 & 70,00 & 75,00 \\
\hline \multicolumn{2}{|c|}{ Maximum } & 72,00 & 72,00 & 83,00 & 88,00 \\
\hline
\end{tabular}

Mean, minimum and maximum postest score of TNU 10 A

\begin{tabular}{llr|r|r|r} 
& & & & \\
& & & & & \\
\hline $\mathrm{N}$ & Palid & 25 & 25 & 25 & 25 \\
\cline { 2 - 6 } & Missing & 0 & 0 & 0 & 0 \\
\hline Mean & 65,8800 & 65,0800 & 74,4800 & 76,8000 \\
\hline Minimum & 60,00 & 60,00 & 69,00 & 70,00 \\
\hline Maximum & 72,00 & 73,00 & 78,00 & 82,00 \\
\hline
\end{tabular}

Mean, minimum and maximum pretest score of TNU 10 B 


\begin{tabular}{|c|c|c|c|c|c|}
\hline & & POSTEST1 & POSTEST2 & POSTEST3 & POSTEST4 \\
\hline \multirow[t]{2}{*}{$\mathrm{N}$} & Valid & 25 & 25 & 25 & 25 \\
\hline & Missing & 0 & 0 & 0 & 0 \\
\hline \multicolumn{2}{|c|}{ Mean } & 69,3600 & 70,0400 & 74,7200 & 81,7600 \\
\hline \multicolumn{2}{|c|}{ Minimum } & 60,00 & 60,00 & 70,00 & 78,00 \\
\hline \multicolumn{2}{|c|}{ Maximum } & 72,00 & 73,00 & 83,00 & 88,00 \\
\hline
\end{tabular}

Mean, minimum and maximum postest score of TNU $10 \mathrm{~B}$

Based on the observation while conducted the treatments, the researcher saw that questioning and answering method type of cooperative learning in reading activity could make the cadets curious about the correct description about the text and how to match it to the picture and also it made them more active in the class. That picture could be used for them to make inference easily because that picture could stimulate the cadets to imagine what person or things look like. and those pictures could make the cadets easily get the information from the text. Those pictures could help them to describe what the texts were about and prepare their brain to construct the meaning conveyed in the text, that pictures could be useful in describing and recognizing meaning of a text when reading.

Questioning and answering method type of cooperative learning also can make the situation in English classroom more fun, therefore cadets' motivation was increased. When the cadets looked at the pictures which actualy described by the text, but the cadets had to read and hear the text first to know the real description, so they could match the text which representated the picture itself. In line with Bannon and Williams's statement (2007) that one of the advantages of using media that media can make the material more interesting. In addition, cadets have extra visualization about what they are reading. Thus, those pictures help them to pay attention to the relevant information.

Pictures helped the cadets to grasp the material. While the cadets guess the thing, place or person after they heard the text, they could find the detail information and construct their imagination to match between picture and text. Moreover the lecturer did not need to explain many things, just showed the pictures that related to the text, to remember in vocabulary and to be understood because one of the characteristic of cadets is their understanding comes not just from explanation, but also from what they see and hear and crucially have chance to touch and interact with.

In treatment activities the researcher also found some cadets who cannot understand the text, when they were asked about the text they got confused, but when they have to make inferences and asked about information from the text, based on the picture they could tell some inferences and information relate to the pictures and text. It showed that the pictures could say what the text could not say. After that, the researcher asked the cadets to read again the text, and it was succesed since they got more understanding after being taught to make inference and get information based on the picture, it could give them imagination and description about the text, about the effectiveness of visual media in teaching reading that visual media is important in a classroom instruction because it can increase accurancy and give meaning to the text.

At the end of the research, it seemed that the cadets could understand how to solve the problems about five aspects of reading. These facts accounted for why their scores increase in the postest. The increase was not only because they were able to use their experience when they were taught using questioning and answering method type of cooperative learning to the next their reading comprehension, but they also knew how to determine main idea, find specific information, make inference, find reference, guess the meaning of difficult words because they used to face the questions which asked about the five aspects of reading when they got the treatments. 


\section{CONCLUSION AND SUGGESTIONS}

Referring to the discussion, the researcher concludes that there is a significant difference of the cadets' reading comprehension after being taught through questioning and answering method type of cooperative learning. The average score in pretest was lower then increased in the postest. It can be said that the cadets' postest score was higher than cadets' pretest score. In addition, there is significant difference of the cadets' reading comprehension before and after being taught through questioning and answering method type of cooperative learning, questioning and answering method type of cooperative learning can be used as an appropriate teaching technique to help the cadets for increasing their reading comprehension. It is intended to stimulate cadets' understanding about the text and able to comprehend the essence of the text. It can be concluded that questioning and answering method type of cooperative learning can increase cadets' reading comprehension at first grade of Aviation Polytechnic of Surabaya.

Referring to the conclusion above, some suggestions can be listed as follows:

1. Based on the findings, it is recomended that English lecturers use the Questioning and answering method, as an alternative way in teaching reading.

2. For the cadets and further researchers who want to develop a research about Questioning and answering method type of cooperative learning, it is suggested that the researcher should control the class activities while matching between text and picture in order to make the cadets more focus.

3. The pictures of descriptive text (learning material) should refer to detail information of the text and fulfill the criteria as a good picture for learning process, clear and refers to whole text.

\section{REFERENCES}

Bannon and Williams. (2007). Identifying Main Ideas: A Basic Aspects of Reading Comprehension. [Online].

Available: www.eric.ed.gov/ERICWebPortal/Search/detailmini.jsp. [12 $2^{\text {th }}$ of December 2013]

Curran, L. 1994. Questioning and answering method Type of Cooperative Learning. http://www.google.com/url=http://eprints.uny.ac.id. Accessed on October $25^{\text {th }}, 2013$.

Djuharie, O. S. 2008. Intensive Reading Bottom-Up Reading. Bandung: Yrama Widya.

Febriana, A. 2011. Application of Cooperative Learning Model Type Questioning and answering method to Enhance Quality Of Learning Social. http://journal.unnes.ac.id/nju/index.php/kreatif/article/view/1678. Accessed on November $23^{\text {rd }}, 2013$.

Grabe, W. and Stoller, F. L. 2001. Reading for Academic Purposes: Guidelines for the ESL/EFL Teachers. In M. Celce-Murcia (Ed). Teaching English as a second or foreign language (3rd ed.). Boston: Heinle and Heinle.

Schumm, J. S. 2006. Reading Assessment and Instruction for All Learners. United States of America: Guilford Press.

Setianingsih, E. and Ahmad. 2012. The Influence of Questioning and answering method Type of Cooperative Learning to Understanding The Ability of Two Variables Linear Equation Systems. http://jurnal.ump.ac.id/index.php/saintis/article/view/60/0. Accessed on November $23^{\text {rd }}, 2013$. 